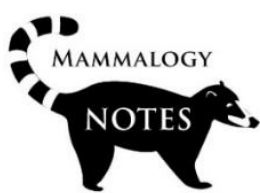

\title{
New records of buffy-tufted-ear marmoset Callithrix aurita (É. Geoffroy, 1812), in a protected area of Teresópolis, Brazilian Atlantic Forest, Brazil
}

\author{
Vitor Guniel Cunha 1,2* (iD), Paulo Rodrigo Diass, (D), Ricardo de Barros Mello Filho 2,5 (D) \\ , Jorge Luiz do Nascimento4 (iD), Carlos Eduardo de Viveiros Grelle ${ }^{6}$ (i) \\ 1 Postgraduate Profissional Biodiversidade em Unidades de Conservação, ENBT-JBRJ, Pacheco Leão St., 2040 - Rio de \\ Janeiro, Brazil, 22460-036*. \\ 2 Environment Secretary, Teresópolis County, 25953-001. \\ 3 Viçosa Federal University - UFV, 36570-900. \\ 4 Centro de Referência em Biodiversidade, Serra dos Órgãos National Park, Instituto Chico Mendes de Conservação da \\ Biodiversidade - ICMBio, 25960-602. \\ 5 Montanhas de Teresópolis Municipal Natural Park, 25980-010. \\ 6 Dept of Ecology, Federal University of Rio de Janeiro, 21941-971. \\ *E-mail: vitor_4596@hotmail.com \\ Resumen
}

Callithrix aurita, un primate endémico de la Mata Atlántica, es una especie amenazada debido a la pérdida de hábitat, la deforestación, la competencia interespecífica y la hibridación. En 2018, entró en la lista de las 25 especies de primates más amenazadas del mundo. Por lo tanto, el registro en nuevos sitios de presencia puede ayudar en su conservación. Presentamos once nuevos registros para la especie en el Parque Natural Municipal de Montanhas de Teresópolis (PNMMT), obtenidos a través de transectos y uso de playback dentro y en áreas aledañas del PNMMT entre marzo de 2020 y enero de 2021. Los nuevos registros provienen de sitios de bosque secundario con altitudes entre 711 y $1000 m$ y refuerzan la importancia del Parque para la conservación de este primate. La presencia de esta especie puede ayudar a la planificación y manejo de esta área protegida, indicando áreas de preservación y la importancia de su entorno.

Palabras clave: especies amenazadas, Primates, áreas protegidas, titíes.

\begin{abstract}
Callithrix aurita, an Atlantic Forest endemic primate, is a threatened species due to habitat loss, deforestation, interspecific competition and hybridization. In 2018, it entered the list of the world's 25-most threatened primate species. Therefore, recording new occurrence sites could help in their conservation. We present eleven new records for the species in the Montanhas de Teresópolis Municipal Natural Park (PNMMT), obtained through observation transects and playback inside and around the PNMMT between March 2020 and January 2021. The new records come from secondary forest sites with altitudes between 711 and $1000 \mathrm{~m}$ and they reinforce the importance of the Park for the conservation of this primate. The presence of this species can help the planning and management of this protected area, indicating areas for preservation and the importance of its surroundings.
\end{abstract}

Key words: endangered species, primates, protected areas, marmosets. 
The Brazilian Atlantic Forest is home to endemic primates, such as the buffy-tufted-ear marmoset, Callithrix aurita (É. Geoffroy Saint-Hilaire, 1812) (Rylands et al., 1996), which occurs in the states of Rio de Janeiro, Minas Gerais and São Paulo, occupying high-altitude forests and, in some cases, lowlands regions (Brandão and Develey, 1998). In 2018, it was included in the list of the 25 most threatened primate species in the world (Carvalho et al., 2019), and it has also been classified as endangered (EN) by the IUCN Red List (Melo et al., 2020) and by the Official Brazilian List of Endangered Species of Fauna (Melo et al., 2018;). The species suffers the impacts of habitat loss, interspecific competition, hybridization and diseases from allochthonous congeners: Callithrix jacchus (Linnaeus, 1758) and Callithrix penicillata (É. Geoffroy Saint-Hilaire, 1812) (Carvalho et al., 2018; Melo et al., 2020).

This note presents new records of $C$. aurita in a protected area in the municipality of Teresópolis, located in the mountainous region of the state of Rio de Janeiro (Fig. 1). This region is part of Serra do Mar mountain range, with the highest potential of conservation and ecotourism of all Brazilian Atlantic Forest (Viveiros de Castro et al., 2021). Teresópolis' remaining Atlantic Forest is preserved by three protected areas (PA): Montanhas de Teresópolis Municipal Natural Park (PNMMT), Três Picos State Park (PETP) and the Serra dos Órgãos National Park (PARNASO).

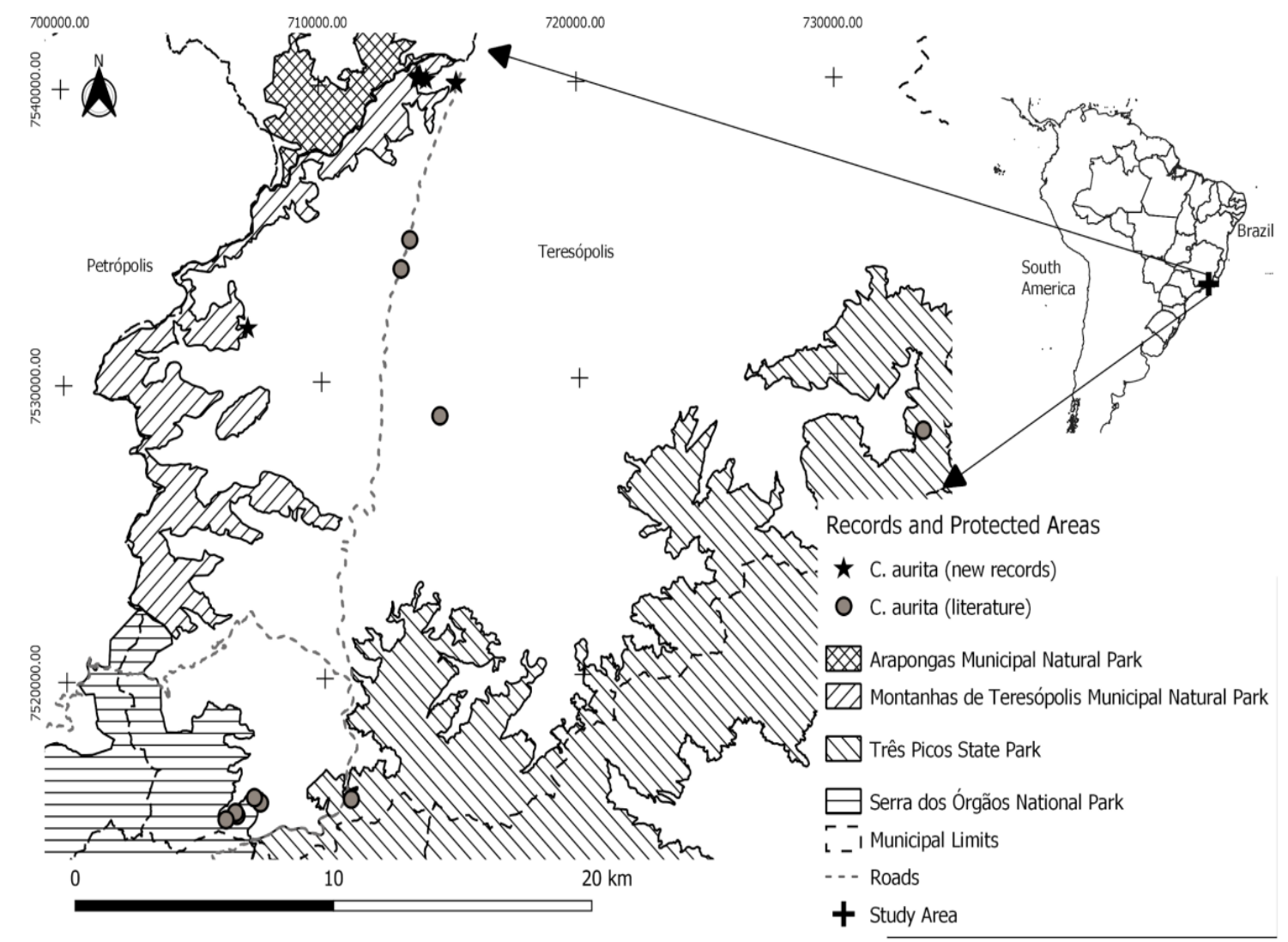

Data Source: CUNHA, 2004; PEREIRA et. al., 2008; ANA, 2010; INEA, 2018; CULOT et. al., 2019. Projection System: UTM Spindle: 23S Datum: Sirgas2000 Organized by: Philippe Ribeiro e Silva, Vitor Cunha, Jorge Luiz Nascimento, Carlos Eduardo de Viveiros Grelle. Jan. 2021.

FIGURE 1. Distribution records of Callithrix aurita in Teresópolis, RJ, Brazil.

The study area (PNMMT) is the largest municipal PA for the Atlantic Forest biome, protecting 4.397 hectares (SOS Mata Atlântica, 2017). Studies on C. aurita have been taken only in PARNASO and PETP, indicating the presence of the species and its allochthonous 
congeners (Pereira et al., 2008; Detogne et al., 2017; Culot et al., 2019; Cronemberger et al., 2019).

Between March 2020 and January 2021, we performed linear transects in the middle of the forest and occasional sampling on nearby roads using playback of the species' vocalization for attracting and making visual contact with it. We recorded the presence of C.aurita 11 times (Table 1), inside and close to the limits of the PNMMT (Fig. 1). All records were obtained in secondary forests between 711 and $1000 \mathrm{~m}$ a.s.l., occasionally with bamboos and near roads. We only report records where visual contact was possible to identify the species.

TABLE 1. Records for Callithrix aurita in Teresópolis, RJ. PNMMT= Montanhas de Teresópolis Municipal Natural Park; PARNASO= Serra dos Órgãos National Park; BR 116= Santos Dumont Highway; V= Visualization; P= Playback; $\mathrm{NI}=$ No information; ** records by playback of genus Callithrix, and without identification of species.

\begin{tabular}{|c|c|c|c|c|c|c|c|c|}
\hline Locality & Date & LAT & LONG & Type & $\begin{array}{l}\text { Hybrid/Exo- } \\
\text { tic sp. Pre- } \\
\text { sence }\end{array}$ & Hour & Altitude & Source \\
\hline PNMMT & $14 / 01 / 2021$ & $-22.230161^{\circ}$ & $-42.924686^{\circ}$ & $V / P$ & NO & $07: 40$ & $848 m$ & This study \\
\hline PNMMT $^{* *}$ & 08/01/2021 & $-22.23043^{\circ}$ & $-42.924061^{\circ}$ & $\mathrm{P}$ & $\mathrm{NI}$ & $07: 20$ & $831 \mathrm{~m}$ & This study \\
\hline BR 116 (Km 57) & $07 / 01 / 2021$ & $-22.232150^{\circ}$ & $-42.910736^{\circ}$ & $V / P$ & YES & $12: 10$ & $711 \mathrm{~m}$ & This study \\
\hline PNMMT & $21 / 12 / 2020$ & $-22.229731^{\circ}$ & $-42.924206^{\circ}$ & V & NO & $08: 40$ & $805 m$ & This study \\
\hline PNMMT & $18 / 12 / 2020$ & $-22.230185^{\circ}$ & $-42.925140^{\circ}$ & V & NO & 07:30 & $851 \mathrm{~m}$ & This study \\
\hline PNMMT & $15 / 12 / 2020$ & $-22.230162^{\circ}$ & $-42.924695^{\circ}$ & $V / P$ & NO & $07: 30$ & $851 \mathrm{~m}$ & This study \\
\hline BR 116 ( Km 57) & $05 / 12 / 2020$ & $-22.231996^{\circ}$ & $-42.910681^{\circ}$ & $V / P$ & YES & $10: 40$ & $714 \mathrm{~m}$ & This study \\
\hline BR 116 ( Km 57) & $18 / 11 / 2020$ & $-22.231742^{\circ}$ & $-42.910617^{\circ}$ & $V / P$ & NO & $11: 20$ & $715 m$ & This study \\
\hline Fazenda dos Caboclos & $18 / 09 / 2020$ & $-22.306652^{\circ}$ & $-42.988965^{\circ}$ & v & YES & $09: 24$ & $\sim 1000 \mathrm{~m}$ & This study \\
\hline PNMMT & $07 / 04 / 2020$ & $-22.230478^{\circ}$ & $-42.925437^{\circ}$ & V & NO & $10: 40$ & $860 m$ & This study \\
\hline $\begin{array}{c}\text { Fazenda Lagoa } \\
\text { Orgânicos }\end{array}$ & $16 / 03 / 2020$ & $-22.230966^{\circ}$ & $-42.921957^{\circ}$ & $V / P$ & NO & $09: 20$ & $830 m$ & This study \\
\hline PARNASO & ago./05 & $-22.449550^{\circ}$ & $-42.986464^{\circ}$ & V & YES & $\mathrm{NI}$ & $\mathrm{NI}$ & Pereira et al., 2008 \\
\hline PARNASO & jul./05 & $-22.454064^{\circ}$ & $-42.993567^{\circ}$ & V & YES & $\mathrm{NI}$ & $\mathrm{NI}$ & Pereira et al., 2008 \\
\hline PARNASO & jun./05 & $-22.454925^{\circ}$ & $-42.993019^{\circ}$ & V & YES & $\mathrm{NI}$ & $\mathrm{NI}$ & Pereira et al., 2008 \\
\hline PARNASO & $08 / 02 / 2004$ & $-22.451119^{\circ}$ & $-42.984167^{\circ}$ & V & NO & $10: 20$ & $950 \mathrm{~m}$ & Cunha, 2004 \\
\hline PETP & $\mathrm{NI}$ & $-22.337697^{\circ}$ & $-42.734777^{\circ}$ & $\mathrm{NI}$ & $\mathrm{NI}$ & $\mathrm{NI}$ & $1908 m$ & Culot et al., 2019 \\
\hline $\mathrm{NI}$ & $\mathrm{NI}$ & $-22.279714^{\circ}$ & $-42.928008^{\circ}$ & $\mathrm{NI}$ & $\mathrm{NI}$ & $\mathrm{NI}$ & $851 \mathrm{~m}$ & Culot et al., 2019 \\
\hline $\mathrm{NI}$ & $\mathrm{NI}$ & $-22.288603^{\circ}$ & $-42.931274^{\circ}$ & $\mathrm{NI}$ & $\mathrm{NI}$ & $\mathrm{NI}$ & $834 \mathrm{~m}$ & Culot et al., 2019 \\
\hline $\mathrm{NI}$ & $\mathrm{NI}$ & $-22.333333^{\circ}$ & $-42.916667^{\circ}$ & $\mathrm{NI}$ & $\mathrm{NI}$ & $\mathrm{NI}$ & $960 m$ & Culot et al., 2019 \\
\hline PETP & $\mathrm{NI}$ & $-22.450000^{\circ}$ & $-42.950000^{\circ}$ & $\mathrm{NI}$ & $\mathrm{NI}$ & $\mathrm{NI}$ & $895 m$ & Culot et al., 2019 \\
\hline
\end{tabular}

In March and April 2020, a group of C. aurita was observed (Fig. 2A) at Fazenda Lagoa Orgânicos, around and inside the PNMMT. In September 2020, at 9:24 AM, we identified one individual with $C$. aurita phenotype and at least four other individuals from Callithrix sp. (Fig. 2B) in a private property located close to the boundaries of the PNMMT (Fazenda dos Caboclos). In November 2020, at 11:20 AM, a solitary male of C. aurita responded to playback (Fig. 2D) near the road BR-116 (km 57; 1,5km the limits of PNMMT). In December 2020, we gathered records in two different dates. A group of four individuals was recorded: one male, one female and two young ones, within the boundaries of the PNMMT, this time close to a Brazilian grape tree (Plinia cauliflora) and bamboo (Fig. 2C). This group was recorded again later in the month, plus two hybrid individuals that were registered next to an individual of C. aurita near BR 116. In January 2021, at 07:40 AM, one male and other sex-unidentified individuals of $C$. aurita were seen inside PNMMT. At 12:10 PM near BR 116, a mixed group of three marmosets was registered, one $C$. aurita male and two sex-unidentified individuals of Callithrix sp. 

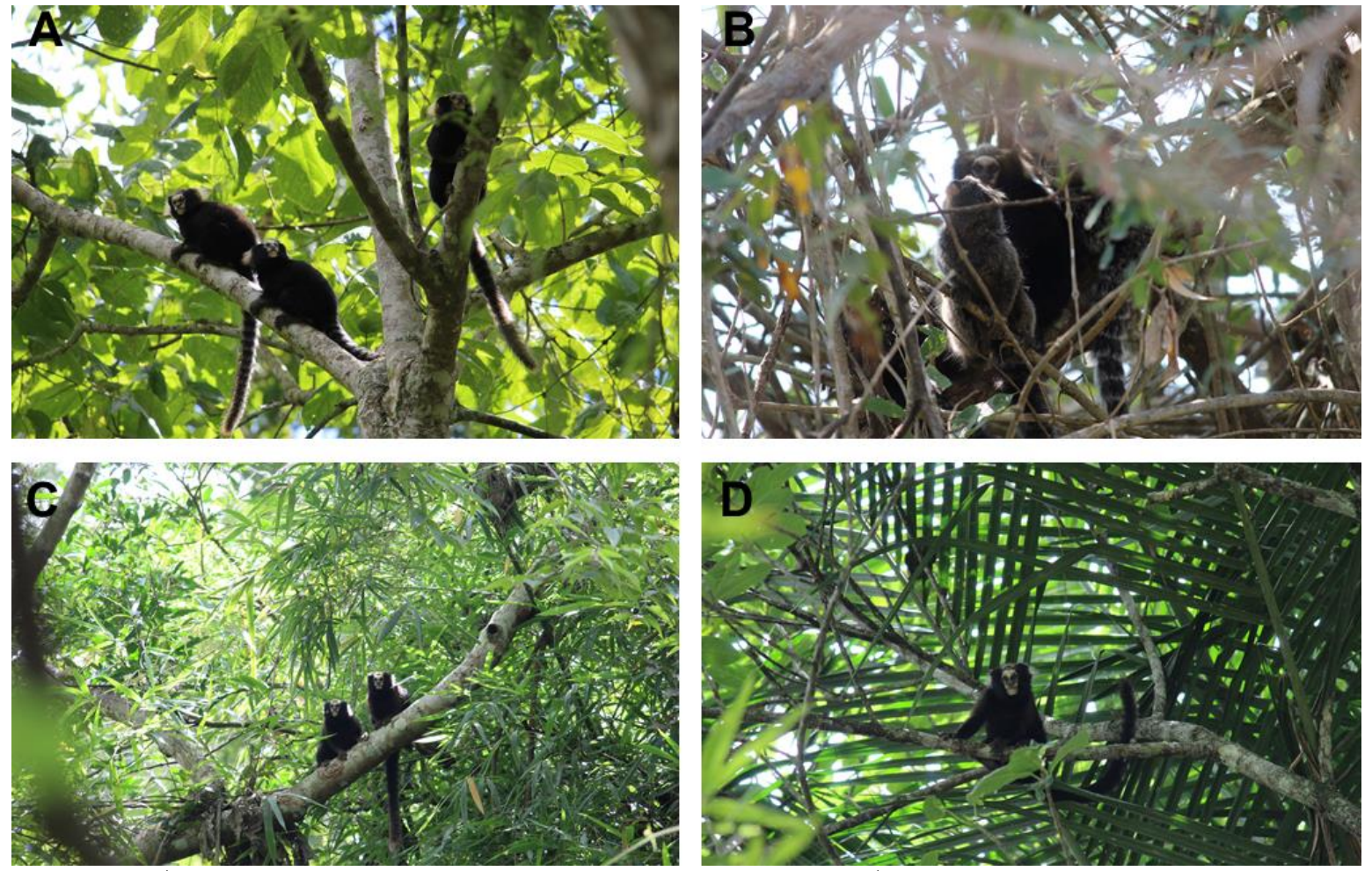

FIGURE 2. A) three individuals of Callithrix aurita, 16/03/2020; B) an individual with Callithrix aurita phenotype together with two hybrid individuals (Callithrix sp.), 18/09/2020; C) two adult individuals of C. aurita, 21/12/2020; D) one adult individual of C. aurita, 18/11/2020.

These new occurrences are located within the expected geographical range (Rylands et al., 2009; Melo et al., 2020) and altitudes (Brandão and Develey, 1998) for Teresópolis. Previously, the only primate registered in the PNMMT was the allochthonous $C$. jacchus (Pereira et al., 2019). The habitats of secondary forest and bamboo presence are the same cited in the literature (for example Norris et al., 2011). These new records inside and outside PNMMT reinforce the importance of a careful planning of the forests adjacent to the protected area, both for the establishment of a buffer zone and area expansions, including conservation actions with the surrounding human communities. In addition, we suggest developing a long-term research, management and conservation program for the identified group, according to the goals of the National Action Plan for the Conservation of Primates of the Brazilian Atlantic Forest (ICMBio, 2018). This program should include the following objectives: i) Quantify group size and home range of C. aurita in the PNMMT region; ii) identify how many groups of $C$. aurita occur in the region, iii) perform genetic studies to verify the genotype of the group; iii) start a continuous monitoring of group (or groups), iv) establish strategies for preventing contact of $C$. aurita with allochthonous species; v) search and identify new areas with $C$. aurita populations. The management actions needed include the definition of priority areas in which the removal of introduced primates might be necessary, since hybridization is recognized as a threat to $C$. aurita (Oliveira \& Grelle 2012).

Primates are commonly flag species (Mittermeier et al., 2005), and the presence of the threatened $C$. aurita in the region potentially encourages actions aimed at forest restoration, helping to achieve goals for the 2021-2030 decade of restoration (Dudley et al., 
2020). Furthermore, Teresópolis may be another municipality using C. aurita as a flag species and guiding conservation actions mentioned above, following the municipalities of Petrópolis and Nova Friburgo that have established actions to preserve the species. Therefore, this region has potential to preserve many populations of this threatened marmosets.

\section{ACKNOWLEDGMENTS}

Amanda Alencar supported the fieldwork and translation, Vinicius Dias and Pheterson Godinho supported the fieldwork, Marcio Port-Carvalho and Leonardo Oliveira made suggestions and comments. Two the anonymous reviewers made useful comments. Norma Parente and Guilherme Rodrigues supported this research. Philippe Ribeiro made the map. Municipal Secretary of the Environment also supported the research. PNMMT and Secretary of Environment of Teresópolis for the logistical and technical support. C.E.V.G. had grants from CNPq (Produtividade em Pesquisa), and support of Instituto Nacional de Ciência e Tecnologia - Ecologia, Evolução e Conservação da Biodiversidade, and PPBio/CNPq/MCTic.

\section{REFERENCES}

Brandão LD, Develey PF. 1998. Distribution and conservation of the buffy-tufted-ear marmoset, Callithrix aurita, in lowland coastal Atlantic forest, south-east Brazil. Neotropical. Primates. 6: 86-88.

Carvalho RS, Fransen SJ, Valença-Montenegro MM, Dunn NJ, Igayara-Souza CA, Port-Carvalho M, Wormell D, Melo FR, Silva A, Lacerda WR., Jerusalinsky L. 2019. Buffy-Tufted- Ear- Marmoset: Callithrix aurita É Geoffroy Saint-Hilaire, 1812. In: Schwitzer C, Mittermeier RA, Rylands AB, Chiozza F, Williamson EA, Byler D, Wich S, Humle T, Johnson C, Mynottand H, McCabe G, editors. Primates in peril: the world's 25 most endangered primates 2018-2020. Washington, DC, Global Wildlife Conservation, p.78-81.

Carvalho RS, Bergallo HG, Cronemberger C, Guimarães-Luiz T, Igayara-Souza CA, Jerusalinsky L, Knogge C, Lacerda WR, Malukiewicz J, Melo FR, Moreira SB, Pereira DG, Pissinatti A, PortCarvalho M, Ruiz-Miranda CR, Wormell D. 2018. Callithrix aurita: a marmoset species on its way to extinction in the Brazilian Atlantic Forest. Neotropical Primates. 24: 1-8.

Cronemberger C, Delciellos AC, Barros CDSD, Gentile R, Weksler M, Braz AG, Teixeira BR, Loretto D, Vilar EM, Pereira FA, Santos JTC, Geise L, Pereira LG, Aguieiras M, Vieira MV, Estrela C, Junger RB, Honorato RS, Moratelli R, Vilela RV, Guimarães RR, Cerqueira R, Costa-Neto SF, Cardoso TS, Nascimento JL. 2019. Mamíferos do Parque Nacional da Serra dos Órgãos: atualização da lista de espécies e implicações para a conservação. Oecologia Australis. 23: 191-214. https:// doi.org/10.4257/ oeco.2019.2302.02

Culot L., Pereira L.A., Agostini I., de Almeida MAB, Alves RSC, Aximoff I., et al. 2019. ATLANTIC-PRIMATES: a dataset of communities and occurrences of primates in the Atlantic Forests of South America. Ecology 100(1): e02525. 10.1002. https:// doi.org/10.1002/ ecy.2525

Cunha AA. 2004. Additional records of primates in the Serra dos Órgãos National Park. Neotropical Primates. 12(1): 30-31.

Detogne N, Ferreguetti AC, Mello JHF, Santana MC, Dias AC, Mota NC). Gonçalves AEC, Souza CP, Bergallo HG. 2017. Spatial distribution of buffy-tufted-ear (Callithrix aurita) and invasive marmosets (Callithrix spp.) in a tropical rainforest reserve in southeastern Brazil. American Journal of Primatology, 79:1-11. https:// doi.org/10.1002/ajp.22718

Dudley N, Gonzales E, Hallett JG, Keenleyside K, Mumba M. 2020. The UN Decade on Ecosystem Restoration (2021-2030): What Can Protected Areas Contribute? In: Hockings M, Newing H, 
Casson S, Verschuuren B, Chassot O, Waithaka J, Weight P, Geldmann J, editors The International Journal of Protected Areas and Conservation. IUCN, Gland, Switzerland, 26:111116. https:// dx.doi.org/10.2305/IUCN.CH.2020.PARKS-26-1ND.en

ICMBio - Instituto Chico Mendes de Conservação da Biodiversidade. 2018. Portaria $n^{\circ} 702$, de 7 agosto de 2018. Diário Oficial da União 153: 57

Melo F, Bicca-Marques J, Ferraz DS, Jerusalinsky L, Mittermeier RA, Oliveira LC, Mittermeier AR, PortCarvalho M, Ruiz-Miranda CR, Valença-Montenegro MM, Cunha R, Vale RDR. 2020. Callithrix aurita. The IUCN Red List of Threatened Species 2020. https://dx.doi.org/10.2305/IUCN.UK.2020-1.RLTS.T3570A166617776.en

Melo FR, Ferraz DS, Valença-Montenegro MM, Oliveira LC, Pereira DG, Port-Carvalho M, 2018. Callithrix aurita (É. Geoffroy Saint-Hilaire, 1812). In: Instituto Chico Mendes de Conservação da Biodiversidade, editors. Livro Vermelho da Fauna Brasileira Ameaçada de Extinção: Vol II Mamíferos. Brasília: ICMBio, p. 206-213.

Mittermeier RA, Fonseca GAB, Rylands AB, Brandon K. 2005. Uma Breve História da Conservação da Biodiversidade no Brasil. Megadiversidade 1: 14-21.

Norris D, Rocha-Mendes F, Marques R, Nobre RA, Galetti M. 2011. Density and Spatial Distribution of Buffy-tufted-ear Marmosets (Callithrix aurita) in a Continuous Atlantic Forest. International Journal of Primatology 32: 811-829.

Oliveira LC, Grelle CEV. 2012. Introduced primate species of an Atlantic Forest region in Brazil: present and future implications for the native fauna. Tropical Conservation Science 5: 112-120. https:// doi.org/10.1177/194008291200500110

Pereira DG, Oliveira MEA, Ruiz-Miranda CR. 2008. Interações entre calitriquídeos exóticos e nativos no Parque Nacional da Serra dos Órgãos - RJ. Espaço e Geografia. 1: 187-114.

Pereira FA, Serafim KN, Gonçalves LCB, Cardoso CAF, Fedullo LPL. 2019. Riqueza oculta: fauna do parque montanhas de Teresópolis. In: Jesus, FLC, Albuquerque VS, editors. Parque Municipal Montanhas de Teresópolis: 10 anos. Teresópolis, Ed UNIFESO, p. 104-168. https://www.unifeso.edu.br/editora/conteudo-pdf.php?pdf=96\&c=series

Rylands AB, Coimbra-Filho AF, Mittermeier RA. 2009. The systematics and distributions of the marmosets (Callithrix, Callibella, Cebuella, and Mico) and Callimico (Callimico) (Callitrichidae, primates). In: Ford SM, Porter LM, Davis LC, editors. The smallest anthropoids: The marmoset/ callimico radiation. New York, Springer, 25-61.

Rylands AB, Fonseca GAB, Leite YLR, Mittermeier RA. 1996. Primates of the Atlantic Forest. In: Norconk MA, Rosenberger AL, Garber PA, editors. Adaptive Radiations of Neotropical Primates. Boston, Springer. https://doi.org/10.1007/978-1-4419-8770-9_2

SOS Mata Atlântica. 2017. Unidades de Conservação Municipais da Mata Atlântica. Relatório Técnico. SOS Mata Atlântica.

Viveiros-de-Castro EB, Lanna AM, Lobo AC, Felaciani F, Bradford RB, Nascimento JL, Grelle, CEV. 2021. The Atlantic Forest trail: reconnecting people, biodiversity and protected areas. In: Marques M.C.M., Grelle C.E.V, editors. The Atlantic Forest: history, biodiversity, threats and opportunities of the megadiverse forest. Switzerland, Springe. https:// doi.org/10.1007/9783-030-55322-7

Editor: Diego J. Lizcano Recibido 2020-02-17

Revisado 2020-02-25

Aceptado 2021-03-29

Publicado 2021-05-12 